\title{
FULL CONTENTS
}

List of figures

List of contributors

Preface

$x$

List of abbreviations

$x i$

List of abbreviations

Table of cases

xiii

Table of legislation

\section{PART I INTRODUCTION}

1 Purpose, approach and outline of the book 2

1.1 Purpose of the book 2

1.2 Approach of the book 4

1.3 Contribution of the book 6

1.4 Outline of the book

1.5 Acknowledgements 8

2 EU climate policy $\quad 10$

2.1 Introduction 10

2.2 Basics of 'climate' and 'policy' 11

2.3 International climate policy 14

2.4 History and origins of EU climate policy 23

2.5 EU climate policy towards 2030 and beyond 26

2.6 The role of cities in climate action 37

2.7 Conclusion 41

\section{PART II ESSENTIAL EU CLIMATE LAW}

3 EU emissions trading system $\quad 44$

3.1 Introduction 44

3.2 Basics of greenhouse gas emissions trading 45

3.3 Emissions trading design and hybrid carbon pricing schemes 48

3.4 The EU ETS Directive 52

3.5 Linking the EU ETS to non-EU emissions trading systems 62

3.6 Implementation problems of the EU ETS and solutions 63

3.7 Conclusion 72

$4 \quad$ Regulation of emissions from non-ETS sectors $\quad 74$

4.1 Introduction 74

4.2 Basics of non-ETS sector greenhouse gas emissions 76 
4.3 The Effort Sharing Regulation 78

4.4 EU instruments to support the Effort Sharing Regulation 86

4.5 Conclusion 96

5 Renewable energy consumption 98

5.1 Introduction 98

5.2 Basics of renewable energy 99

5.3 The development of renewable energy legislation 102

5.4 The Renewable Energy Directive 106

5.5 Financial support for renewable energy 118

5.6 Conclusion 128

$6 \quad$ Energy efficiency 130

6.1 Introduction 131

6.2 Basics of energy efficiency 132

6.3 The Energy Efficiency Directive 134

6.4 Energy efficiency of buildings 143

6.5 Energy efficiency of appliances 148

6.6 Energy efficiency of various other products 151

6.7 Conclusion 154

7 Carbon capture and storage $\quad 156$

7.1 Introduction 156

7.2 Basics of carbon capture and storage 157

7.3 The Carbon Capture and Storage Directive 160

7.4 Regulation of $\mathrm{CO}_{2}$ capture, transport and storage 164

7.5 Review of the CCS Directive 180

7.6 Offshore CCS deployment 181

7.7 Conclusion 188

$8 \quad$ Regulation of fluorinated gases 190

8.1 Introduction 190

8.2 Basics of fluorinated gases 191

8.3 The Mobile Air-Conditioning Directive 194

8.4 The F-gas Regulation 198

8.5 Conclusion 204

PART III OVERARCHING ISSUES IN EU CLIMATE REGULATION

$9 \quad$ EU climate law and energy network regulation 207

\begin{tabular}{ll}
9.1 & Introduction \\
\hline
\end{tabular} 
9.2 Challenges of decarbonizing energy networks 208

9.3 Energy networks and network governance in the EU 210

9.4 Decarbonizing electricity networks 218

9.5 Conclusion 234

10 Multi-level governance in EU climate law 237

$\begin{array}{ll}10.1 \text { Introduction } & 237\end{array}$

10.2 Multi-level governance and EU climate law 239

10.3 EU climate law and intra-EU multi-level governance 242

10.4 EU climate law and international multi-level governance 253

10.5 Conclusion 257

11 Human rights and EU climate law 259

11.1 Introduction $\quad 259$

11.2 International human rights law and climate change 261

11.3 European human rights law and climate change 268

11.4 Effectuating human rights within EU climate law 272

11.5 Human rights and European climate litigation 282

11.6 Conclusion 291

\section{PART IV CONCLUSION}

12 The past and possible future of EU climate law 294

12.1 Introduction $\quad 294$

12.2 General lessons from the past 294

12.3 Specific lessons for cost-effectiveness and solidarity 297

12.4 The broader picture of EU climate regulation 298

12.5 EU climate law's possible future $\quad 300$

12.6 Conclusion 303

$\begin{array}{ll}\text { Index } & 304\end{array}$ 